\title{
HET ONTWERP VAN WET OP DE JAARREKENING
}

\section{VAN ONDERNEMINGEN}

\author{
door G. Timmer
}

Het in de Troonrede 1967 aangekondigde ontwerp van wet op de jaarrekening van ondernemingen is door de Minister van Justitie op 13 mei 1968 bij de Tweede Kamer der Staten-Generaal ingediend.

Hiermede is een nieuwe belangrijke fase ingeluid in de ontwikkeling van de jaarverslaggeving hier te lande. Zonder twijfel mag immers worden gesteld dat het ontwerp, na tot wet te zijn verheven, van grote betekenis zal zijn voor de wijze waarop ondernemingen hun jaarrekeningen in de toekomst zullen presenteren. De intensieve bemoeienis die de accountant in de uitoefening van zijn hoofdfunctie met die jaarrekeningen heeft, houdt ook voor hem de noodzaak in om aan het thans voor ons liggende ontwerp grote aandacht te besteden. Met het oog hierop vond de redactie het gewenst om spoedig na de publikatie van het ontwerp een beschouwing daarover in dit maandblad te doen opnemen. Schrijver dezes heeft gemeend aan de bedoelingen van de redactie het beste te kunnen voldoen met een in hoofdzaak informatief artikel.

Zoals te verwachten was is de algemene opzet van het ontwerp grotendeels in overeenstemming met het voorontwerp, zoals dit is opgenomen in het rapport van de Commissie-Verdam $\left.{ }^{1}\right)$. Dit neemt niet weg dat op een aantal, deels belangrijke detailpunten wijzigingen zijn aangebracht. Vele van deze wijzigingen zijn voortgevloeid uit suggesties van de door de Minister van Justitie geraadpleegde SociaalEconomische Raad, die in zijn Advies inzake de wetgeving over de jaarrekening van ondernemingen ${ }^{2}$ ) zijn inzichten kenbaar heeft gemaakt aangaande de voorstellen van de Commissie-Verdam met betrekking tot de jaarverslaggeving. Voor een deel zijn de wijzigingen (ook) geïnspireerd door opmerkingen die door anderen over het voorontwerp zijn gemaakt; met name moet in dit verband worden genoemd de gezamenlijke Nota d.d. 27 juli 1966 van de besturen van het N.I.v.A. en de V.A.G.A. aan de Minister van Justitie over zowel het voorontwerp-Verdam, als genoemd advies van de S.E.R. ${ }^{3}$ )

In de laatste paar jaren is in de vakpers aan het voorontwerp-Verdam in ruime mate aandacht besteed ${ }^{4}$ ). Voor wat de algemene karakteristiek van het huidige ontwerp betreft kan daarom met een betrekkelijk summiere beschouwing worden volstaan.

\section{Algemene karakteristiek van het ontwerp van wet}

Ruime vrijheid, binnen een bepaalde - aanvaardbare - gebondenheid. Dit is de algemene typering die wij na eerste kennisneming boven het ontwerp zouden willen plaatsen.

1) Herziening van het ondernemingsrecht, 's-Gravenhage 1965 (hoofdstuk IV).

2) Uitgave van de Sociaal-Economische Raad, 1966, no. 4.

3) Genoemde Nota is gepubliceerd in „de Accountant" van juli/augustus 1966, blz. 583 c.v.

4) De belangstellende lezer zij verwezen naar de literatuurlijst die na het einde van dit artikel is opgenomen. 
Een gebondenheid ten aanzien van het inzicht dat door balans, winst- en verliesrekening en toelichting te zamen moet worden verschaft; dit inzicht moet namelijk zodanig zijn, dat een verantwoord oordeel kan worden gevormd omtrent het vermogen en het resultaat der onderneming. Een ruime vrijheid ten aanzien van de vorm, waarin die informatie zal worden verstrekt, en ook - hetgeen nog veel belangrijker is - ten aanzien van de keuze van de grondslagen waarop de waardering van de activa en passiva in de balans en de bepaling van het resultaat zal berusten, mits men maar blijft binnen de normen die daarvoor in het maatschappelijk verkeer aanvaardbaar worden geacht.

Bij de opzet van het ontwerp is men dus, het zij met genoegen geconstateerd, in dezelfde richting gegaan als eerder door de Commissie-Verdam was ingeslagen. Wij zullen door de onderhavige wet gelukkig dus niet gedrongen worden in een stelsel van straffe vormvoorschriften en verplichte waarderingsmethoden, hetwelk, wij zien de voorbeelden daarvan in Duitsland, zo gemakkelijk tot verstarring leidt en tot een formalisering van de arbeid van de accountant. In de opzet van het ontwerp bestaat de mogelijkheid waarderingsgrondslagen te kiezen die in een concreet geval het meest in aanmerking komen en deze indien nodig aan te passen aan gewijzigde bedrijfseconomische inzichten.

Bedrijfseconomische inzichten. Wij zijn ons ervan bewust dat het door menig collega zal worden betreurd ${ }^{5}$ ) dat het volgens artikel 5 van het ontwerp de in het maatschappelijk verkeer aanvaardbaar geachte normen zijn, die als grondslag voor waardering en resultatenbepaling zullen dienen en met name dus niet de normen die berusten op bedrijfseconomisch verantwoorde beginselen. In de Memorie van Toelichting is een drieledige verklaring gegeven voor het feit dat men niet zo ver heeft willen gaan, t.w.:

- de wetenschappelijke beoefening van de bedrijfseconomie is nog te zeer in beweging om in de wet een bepaalde methode vast te leggen;

- sommige waarderingsgrondslagen lenen zich voor bepaalde bedrijfstakken beter dan andere;

- het is van belang de toekomstige ontwikkeling niet af te snijden.

Hoewel wij van mening zijn dat een zich baseren op bedrijfseconomische normen stellig niet tot afsnijding van de toekomstige ontwikkeling zou behoeven te leiden, hebben wij er volledig begrip voor dat zodanige normen (nog) niet als algemene grondslag in een wet op de jaarrekening kunnen worden gehanteerd. In dezelfde gedachtengang kwamen de besturen van het N.I.v.A. en de V.A.G.A. tot de overweging "dat bedrijfseconomische inzichten reeds in belangrijke mate invloed op de maatschappelijk aanvaardbare normen hebben uitgeoefend en onder invloed van de evolutie van de bedrijfseconomie steeds verder in deze normen zullen doorwerken"6).

Aan het aloude begrip "goed koopmansgebruik" is, o.i. terecht, evenmin een plaats in het ontwerp toegekend, het heeft een te ruime betekenis gekregen. Terloops zij in dit verband vermeld, dat op dit punt een aanpassing nodig zal zijn van de Regelen Beroepsuitoefening Registeraccountants; deze houden namelijk nog de

5) Zie b.v. Prof. A. B. Frielink in zijn artikel in dit maandblad van april 1966, blz. 142 e.v. en Drs. H. H. J. Nordemann in zijn openbare les ,Wensen en grenzen”, blz. 15 e.v.

6) Nota d.d. 27 juli 1966, de Accountant juli/augustus 1966, blz. 587.

m a b blz. 299 
bepaling in dat de goedkeurende verklaring bij een jaarrekening impliceert dat deze is opgemaakt volgens goed koopmansgebruik.

Intussen houdt de bewust gegeven vrijheid een belangrijke taakstelling voor de nabije toekomst in, èn voor het bedrijfsleven, èn voor de beoefenaren van het accountantsberoep. Het is namelijk een onontkoombare noodzaak om tot een zekere objectivering van de in het maatschappelijk verkeer aanvaardbaar geachte normen te geraken. Men denke slechts aan de toetsingsmogelijkheid waarover de ondernemingskamer van het Gerechtshof te Amsterdam (waarover later) t.z.t. moet kunnen beschikken. In herinnering moge hier worden gebracht dat J. Kraayenhof in zijn rede tijdens de eerste ledenvergadering van het N.I.v.R.A. ${ }^{7}$ ) een pleidooi heeft gehouden voor een inventarisatie van waarderingsgrondslagen en andere richtlijnen en voor de toetsing op aanvaardbaarheid daarvan in overleg tussen een daartoe door de Raad van Werkgeversverbonden aan te wijzen commissie en een te vormen Instituuts-commissie. Voor de instelling van een „Commissie van advies inzake de jaarverslaggeving" hebben ook Drs. W. van Bruinessen en Drs. J. W. Schoonderbeek in op 17 en 24 september 1966 gehouden studievergaderingen van het N.I.v.A. en de V.A.G.A. gepleit ${ }^{8}$ ).

Degenen die in de toekomst tot deze arbeid geroepen zullen worden, zullen geen eenvoudige taak te vervullen krijgen. Enerzijds zou immers die objectivering van waarderingsgrondslagen zo concreet moeten zijn dat zij cen bruikbare toetsingsmogelijkheid biedt, anderzijds moet tot elke prijs worden voorkomen dat wij door een te vér gaande detaillering toch in een verstarring zouden geraken.

De kern van bet ontwerp, de omschrijving van het doel van de jaarrekening, vinden wij in artikel 2:

„De jaarrekening geeft een zodanig inzicht dat een verantwoord oordeel kan worden gevormd omtrent het vermogen en het ,resultaat der onderneming, alsmede voor zover de aard van een jaarrekening dat toelaat, omtrent haar solvabiliteit en liquiditeit".

De in deze doelomschrijving cursief gedrukte woorden vormen de belangrijkste wijzigingen daarin ten opzichte van de doelomschrijving in het voorontwerp-Ver$\mathrm{dam}$. Het resultaat is in de plaats gekomen voor de rentabiliteit, waarmede tegemoetgekomen is aan de van verschillende kanten gemaakte opmerking ${ }^{9}$ ), dat voor het verkrijgen van inzicht in de rentabiliteit van een onderneming als regel meer gegevens nodig zijn dan in de jaarrekening voorkomen.

Door de toevoeging van de woorden ,voor zover de aard van een jaarrekening dat toelaat", zijn op eenvoudige wijze de bezwaren afgedaan van hen ${ }^{10}$ ) die terecht - hebben betoogd dat de jaarrekening alléén geen goed instrument is om de solvabiliteit en liquiditeit van een onderneming te beoordelen.

Het zojuist geciteerde artikel 2 is, zoals wij reeds schreven, de kern van het ontwerp. Dit blijkt duidelijk uit de Memorie van Toelichting en het wordt nog eens onderstreept door de bewoordingen van de eerste zin van artikel 4: „De samen-

7) Zie de Accountant van mei 1967, blz. 18

8) Zie de Accountant van februari 1967, blz. 279.

9) Zie b.v. Prof. A. B. Friclink in dit maandblad van april 1966, blz. 141 en de nota d.d. 27 juli 1966 van de besturen, de Accountant juli/augustus 1966, blz. 585.

10) Zie b.v. Prof. G. L. Groeneveld in De Naamloze Vennootschap van april/mei 1965, blz. 9. 
voeging, de ontleding en de rangschikking der gegevens in de jaarrekening zijn gericht op het inzicht dat de jaarrekening krachtens artikel 2 beoogt te geven". Doordat artikel 4 verder bepaalt dat daarbij in ieder geval de voorschriften, vervat in de hoofdstukken II en III in acht zijn te nemen, hebben die voorschriften (die meer in concreto handelen over afzonderlijke posten van balans en winst- en verliesrekening) het karakter van minimum-voorschriften gekregen.

Het voorgaande betekent dat men, wanneer men zich gesteld ziet voor de vraag hoe een bepaald gegeven of een bepaalde situatie in de jaarrekening zal worden weergegeven, in de eerste plaats moet nagaan of bij de te kiezen presentatiewijze aan de algemene eis van artikel 2 zal worden voldaan. Vervolgens moet dan de vraag worden beantwoord of daarmede ook in overeenstemming zal worden gehandeld met de - wat formelere - voorschriften van hoofdstuk II en/of III. Wanneer die hoofdstukken voor een bepaalde situatie geen aanwijzing bevatten, staat nochtans in algemene zin vast hoe de gevolgen van die situatie in de jaarrekening moeten worden verwerkt, namelijk zodanig, dat een verantwoord oordeel kan worden gevormd omtrent het vermogen en het resultaat. Het is duidelijk, dat zowel in het ene als in het andere geval bedrijfseconomische inzichten bij het opmaken van de jaarrekening een belangrijke rol spelen.

Wij schreven dat de bepalingen in de hoofdstukken II en III het karakter van minimum-voorschriften dragen. Dit houdt in dat een gegeven, dat in het kader van een bepaalde jaarrekening onbelangrijk en dus voor het verlangde inzicht van geen betekenis moet worden geacht, somtijds niettemin afzonderlijk in de jaarrekening zal moeten worden getoond. Aangezien men de vrijheid heeft om gegevens, waarvan het verstrekken verplicht is gesteld, desgewenst in de toelichting onder te brengen (artikelen 9 en 27 van het ontwerp), zullen de balans en winsten verliesrekening zélf als regel wel van onbelangrijke details ontdaan kunnen blijven. Niettemin betreuren wij het, dat in het ontwerp geen bepaling voorkomt in de geest van de Amerikaanse Rule 3-0211): „If the amount which would otherwise be required to be shown with respect to any item is not material, it need not be separately set forth in the manner prescribed". In dezelfde geest is ook een voorstel gedaan door de besturen van het N.I.v.A. en de V.A.G.A.12) De Minister heeft een zodanige bepaling niet aangedurfd; hij is blijkens de Memorie van Toelichting van mening dat het in de hoofdstukken II en III om gegevens van zodanige betekenis gaat, dat het geen aanbeveling verdient om de beslissing over het al of niet vermelden van die gegevens aan een subjectieve beoordeling van de relatieve belangrijkheid over te laten. Wij zijn van gevoelens dat het meer in de lijn van de gehele opzet van het ontwerp had gelegen, indien zulks wel zou zijn geschied.

In het voorgaande hebben wij reeds melding gemaakt van de algemene eisen waaraan de in de jaarrekening gehanteerde waarderingsgrondslagen moeten voldoen. Eenmaal gekozen grondslagen, waaromtrent de toelichting een uiteenzetting moet bevatten (artikel 5, lid 2), dienen in beginsel volgens een bestendige gedragslijn artikel 3 zegt „stelselmatig” - te worden toegepast. Indien het om enige reden

11) Van Regularion S-X, uitgevaardigd door de Securities and Exchange Commission.

12) Zie de nota van de besturen, de Accountant juli/augustus 1966, blz. 586, het gedeelte dat handelt over artikel 4 van het voorontwerp. 
noodzakelijk is die bestendige gedragslijn te doorbreken, moet de wijziging in de grondslagen, indien zij van wezenlijk belang is, uitdrukkelijk worden vermeld, onder mededeling van haar invloed op het vermogen en het resultaat (artikel 5, lid 3). Indien in dit opzicht aan de bepalingen van de wet is voldaan, d.w.z. indien (a) in het maatschappelijk verkeer als aanvaardbaar beschouwde grondslagen zijn toegepast en (b) ten opzichte van het voorgaande jaar geen wijziging in die grondslagen heeft plaats gevonden of van (een) wijziging(en) op de juiste wijze mededeling is gedaan, behoeft in de accountantsverklaring naar onze mening ter zake niets te worden vermeld.

Het vorenstaande is in overeenstemming met de gevestigde opvatting hier te lande en het betekent dus dat ook in de toekomst in de goedkeurende verklaring geen tirade behoeft te worden opgenomen in de zin van het laatste gedeelte van de Amerikaanse standaardverklaring: ,in conformity with generally accepted accounting principles applied on a basis consistent with that of the preceding year"13), eventueel aangevuld met bewoordingen als „except for the change as explained in Note $X$ to the financial statements, with which we concur"14).

De goedkeurende verklaring zal onder de werking van de Wet op de jaarrekening van ondernemingen impliciet de instemming van de accountant met de betrokken punten inhouden, zoals die goedkeurende verklaring trouwens in het algemeen, zonder dat daarvan uitdrukkelijk melding is gemaakt, zal betekenen dat de jaarrekening voldoet aan de voorschriften van genoemde wet. Dit volgt zonder meer uit de laatste zin van artikel 8 der wet: „,Voor zover de jaarrekening niet aan de ,bepalingen van deze wet voldoet, maakt de verklaring daarvan melding”.

Wij achten het een gelukkige omstandigheid, dat in het ontwerp niet het omgekeerde wordt verlangd, namelijk dat in de accountantsverklaring (zoals b.v. in Duitsland) expliciet wordt vermeld dat aan de bepalingen van de wet is voldaan. Een zodanige vermelding zou immers gemakkelijk tot de gedachte kunnen leiden dat de verklaring van de accountant niet meer betekent dan dat is vastgesteld, dat de jaarrekening in overeenstemming is met de (formele) wettelijke bepalingen en dat zij geen eigen op bedrijfseconomische gronden gefundeerd oordeel van de accountant inhoudt.

\section{Werkingssfeer; publikatieplicht; verplichte accountantscontrole}

De wet heeft betrekking op de jaarrekeningen van ondernemingen, waarbij onder een onderneming in de zin van de wet wordt verstaan (artikel 1):

- de naamloze vennootschap

- de coöperatieve vereniging

- de onderlinge waarborgmaatschappij

- de landbouwkredietbank - niet uitsluitend spaarbank zijnde - ook indien zij geen coöperatieve vereniging is.

Behoudens drie uitzonderingen zijn alle ondernemingen die onder deze definitie vallen verplicht hun jaarrekeningen met inachtneming van de onderhavige wet op te stellen.

13) Zie Statement on Auditing Procedure No. 33, Chapter 10, gepubliceerd door het American Institute of Certified Public Accountants.

14) Het voorgaande sluit uiteraard niet uit dat cen Nederlands accountant, b.v. indien zijn verklaring (medc) voor het Amerikaanse verkeer is bestemd, een dergelijke tirade niettemin zal kunnen opnemen. 
De eerste uitzondering vormen de verzekeringsondernemingen, die de ingevolge de wet op de jaarrekening verlangde gegevens niet in de jaarrekening behoeven te vermelden, voor zover die gegevens voorkomen in het verslag bedoeld in de Wet op het Levensverzekeringsbedrijf of de Wet op het schadeverzekeringsbedrijf, welk verslag tevens geldt als een jaarrekening overeenkomstig de onderhavige wet (artikel 36, lid 1). In materieel opzicht zijn de bepalingen van de onderhavige wet voor de verzekeringsondernemingen dus toch van evenveel betekenis als voor de overige ondernemingen.

De Nederlandsche Bank N.V. wordt in artikel 37 afzonderlijk genoemd en is daarmede de tweede uitzondering op de algemene regel; met betrekking tot haar jaarrekening kan van de bepalingen van de wet worden afgeweken, voor zover dit voor de vervulling van haar in de Bankwet 1948 omschreven taak naar het oordeel van haar raad van commissarissen en van haar Koninklijke Commissaris noodzakelijk is.

De derde uitzondering betreft de onderneming waarvan meer dan de helft van het geplaatste kapitaal in handen van een andere onderneming is, waarop voorts niet de hierna te behandelen publikatieplicht rust en waarvan tenslotte alle aandeelhouders of leden vóor de afloop van het boekjaar hebben verklaard, dat de jaarrekening niet volgens de eisen van de wet zal behoeven te worden ingericht (artikel 13, lid 3). Op de achtergrond van deze uitzondering komen wij in paragraaf V (Deelnemingen) terug.

Niet onder de werkingssfeer van de wet vallen derhalve natuurlijke personen, vennootschappen onder firma, commanditaire vennootschappen, verenigingen (behalve coöperaties) en stichtingen.

De bestaande publikatieplicht van bepaalde naamloze vennootschappen, waarmede wordt bedoeld de verplichting tot neerlegging van volledige afschriften van balans, winst- en verliesrekening en toelichting ten kantore van het handelsregister binnen acht dagen na de vaststelling van die stukken (welke vaststelling zal moeten geschieden binnen zes - thans negen - maanden na afloop van het boekjaar), wordt door het onderhavige wetsvoorstel niet gewijzigd, met dien verstande dat deze deponeringsverplichting door de bepaling van artikel 8, lid 2 mede betrekking gaat hebben op de accountantsverklaring. Voor welke naamloze vennootschappen deze publikatieplicht geldt bepaalt onveranderd artikel $42 \mathrm{c}$ van het Wetboek van Koophandel, t.w.:

- die waarvan de statuten aandelen aan toonder tot een hoger bedrag dan $f 50.00015$ ) toelaten;

- die waarvan aandelen aan toonder en/of certificaten aan toonder van aandelen op naam tot een gezamenlijk bedrag van meer dan $f 50.00015$ ) in omloop zijn;

- die welke obligaties aan toonder hebben uitstaan of waarvan certificaten aan toonder van obligaties op naam in omloop zijn;

- die waarvan aandelen of obligaties of certificaten van deze stukken zijn opgenomen in de prijscourant van de Amsterdamse effectenbeurs;

- die welke (mede) het bank- of verzekeringsbedrijf uitoefenen.

\footnotetext{
15) De Commissie-Verdam heeft voorgesteld deze bedragen tot $f 250.000$ (geplaatst) te verhogen; dit voorstel is door de Minister van Justitie niet overgenomen.
}

m a b blz. 303 
Voor coöperatieve verenigingen, waarvan de som van de activa tenminste $f 3$ miljoen bedraagt, zal een overeenkomstige publikatieplicht gelden, waaraan binnen een maand na de goedkeuring van de jaarrekening, d.w.z. binnen zes maanden na afloop van het boekjaar, moet worden voldaan. Eenzelfde verplichting zal rusten op de landbouwkredietbank, die aan vorengenoemd critirium voldoet, ook indien die geen coöperatieve vereniging is.

Hoewel de bestaande publikatieplicht van naamloze vennootschappen door de onderhavige wet dus niet zal worden gewijzigd, heeft de Minister in de Memorie van Toelichting wel enige gedachten ontwikkeld om, in afwachting van de ontwikkelingen in Europees verband, toch tot een zekere uitbreiding van de publikatieplicht te komen, en wel voor wat betreft bepaalde besloten naamloze vennootschappen. Hij denkt daarbij aan de volgende maatregelen, ten aanzien waarvan hij voornemens is de indiening van een wetsontwerp tot wijziging van het Wetboek van Koophandel te bevorderen:

a. het instellen van een publikatieplicht voor besloten naamloze vennootschappen welke een balanstotaal van $f 8$ miljoen en hoger uitwijzen, echter met een mogelijkheid tot vrijstelling van deze verplichting voor bepaalde besloten naamloze vennootschappen welke dochterondernemingen zijn en aan nader te bepalen voorwaarden voldoen;

b. het scheppen van de mogelijkheid tot publikatie van een vereenvoudigde balans door de onder a. bedoelde besloten naamloze vennootschappen.

Het zou ons te ver voeren om verder op deze gedachten in te gaan, zij werden slechts volledigheidshalve vermeld.

Tenslotte in deze paragraaf nog de vraag te beantwoorden voor welke ondernemingen de jaarrekening van een deskundige-verklaring moet worden voorzien. Dit zijn, kort gezegd:

- alle naamloze vennootschappen met een geplaatst kapitaal van tenminste $f 500.000$, en voorts

- alle ondernemingen waarvoor blijkens het voorgaande een publikatieplicht bestaat.

Door de instelling van het eerste criterium, dat ook geldt indien b.v. alle aandelen op naam zijn gesteld, worden ook de grotere besloten naamloze vennootschappen verplicht hun jaarrekening te doen controleren.

Als deskundige dient, behoudens in het volgende geval, altijd een registeraccountant te fungeren, wiens benoeming $k a n$ geschieden door de algemene vergadering van aandeelhouders (artikel 42a W.v.K.) en, indien deze vergadering een desbetreffend besluit niet heeft genomen, moet geschieden door commissarissen (artikel 51 b W.v.K.).

De uitzondering waarop werd gedoeld is deze, dat het onderzoek eveneens mag worden verricht door een buitenlandse deskundige, die daartoe door de Minister van Economische Zaken bij een herroepelijke vergunning is toegelaten op grond van een bewijs van bekwaamheid dat in het buitenland is verkregen. De Minister kan aan deze vergunning voorwaarden verbinden en in de Memorie van Toelichting is tot uitdrukking gebracht, dat het in de bedoeling ligt daarbij o.m. het wederkerigheidsbeginsel toe te passen. Op deze wijze is uitvoering gegeven aan het voor- 
stel dat de besturen van het N.I.v.A. en de V.A.G.A. in hun brief aan de Minister van Justitie van 25 januari 196716) hebben gedaan. Hierbij zij aangetekend, dat de besturen blijkens hun genoemde brief kennelijk een vergunning per geval (de in de Verenigde Staten door de Securities and Exchange Commission gevolgde gedragslijn) op het oog hadden, terwijl de bewoordingen van het ontwerp het afgeven van een, zij het herroepelijke, vergunning aan een bepaalde buitenlandse accountant in bet algemeen (de regeling in de Companies Act van het Verenigd Koninkrijk) mogelijk maken.

Een belangrijk facet waarop nog de aandacht moet worden gevestigd is het volgende. In de Memorie van Toelichting wordt bij de bespreking van artikel 8 gezegd dat het ontwerp niet uitsluit dat de verklaring door de accountant wordt afgelegd in naam van de maatschap waaraan hij deelneemt, zoals in de praktijk dikwijls voorkomt. Wij menen dat deze uitspraak zo moet worden verstaan dat, indien het bij een maatschap gebruikelijk is verklaringen met de naam van de maatschap zonder meer te ondertekenen, dit gebruik kan worden gehandhaafd. Met het oog op het fungeren van de Nederlandse accountant in het internationale verkeer is dit van grote betekenis. Het bedoelde gebruik is in de Angelsaksische landen, die te dezen opzichte voor het accountantsberoep als toonaangevend kunnen worden beschouwd, immers vrijwel algemeen.

\section{De balans met de toelichting}

„De balans met de toelichting”, zo zegt artikel 3, lid 1, ,geeft getrouw en stelselmatig de grootte en de samenstelling van het vermogen van de onderneming op het einde van het boekjaar weer".

Hoofdstuk II bevat een aantal bepalingen met betrekking tot afzonderlijke groepen van activa en passiva, waarbij steeds geldt dat de mededeling van verplicht gestelde gegevens naar keuze kan geschieden, hetzij op de balans, hetzij in de toelichting (artikel 9).

In deze paragraaf zullen wij de bepalingen voor afzonderlijke groepen van activa en passiva in vogelvlucht bezien. Gelet op het belang en de omvang der bepalingen welke betrekking hebben op het houden van deelnemingen, zullen deze echter in een afzonderlijke paragraaf worden behandeld.

Vaste activa (artikel 10)

Ten aanzien van deze post moet allereerst onderscheid worden gemaakt tussen wél en nièt in het produktieproces opgenomen vaste activa, terwijl voor de activa uit de eerste groep een verdere categorische indeling wordt verlangd, tenminste in (a) bedrijfsgebouwen en -terreinen, (b) machines en installaties en (c) andere duurzame produktiemiddelen.

De wat vreemd aandoende bepaling ${ }^{17}$ ) uit het voorontwerp, dat vervoerbedrijven de vervoermiddelen afzonderlijk zouden moeten vermelden, is in het onderhavige wetsvoorstel niet overgenomen.

Uit de redactie van artikel 10 en de Memorie van Toelichting moet worden geconcludeerd, dat met het uitsluitend verstrekken van een functionele specificatie

16) Gepubliceerd in de Accountant van maart 1967, blz. 319 e.v.

17) In deze zin ook getypeerd door Prof. Dr. H. J. van der Schroeff in zijn artikel in dit maandblad, juni 1965, blz. 230 . 
van de vaste activa, welke mogelijkheid de S.E.R. had willen openlaten ${ }^{18}$ ), niet mag worden volstaan. Wel kunnen uiteraard de vaste activa van een onderneming met verschillende fabrieken eerst naar die fabrieken worden gesplitst, doch dan dient voor elke fabriek afzonderlijk, of voor alle fabrieken te zamen, tevens een categorische indeling als vorenbedoeld te worden verstrekt.

Het is reeds enkele malen gezegd: in de keuze der waarderingsgrondslagen voor de opname van een post in de balans is men, binnen ruime grenzen, vrij. Dit betekent dat b.v. een waardering van vaste activa op historische kostprijs minus systematische afschrijvingen is toegestaan en dat in bepaalde gevallen opname van een waardevol actief (b.v. het kantoorgebouw van een bank) voor een symbolisch bedrag aanvaardbaar zal zijn te achten. Hierbij moet echter altijd de aan het begin van deze paragraaf geciteerde algemene bepaling van artikel 3 in het oog worden gehouden, waaruit volgt dat, indien de gebruikte waarderingsmethode op zichzelf niet tot een getrouwe vermogenspresentatie in de balans leidt, de toelichting zodanige aanvullende inlichtingen zal moeten bevatten dat niettemin cen redelijk oordeel over het vermogen kan worden gevormd. Of in dit opzicht het vermelden van verzekerde waarden een adequaat middel is, zou in verschillende gevallen kunnen worden betwijfeld. Het zou ons te ver vocren thans nader op dit aspect in te gaan; het zal ongetwijfeld in de toekomst de gedachten nog veelvuldig bezighouden.

Tenslotte zij opgemerkt dat in het ontwerp de aanbeveling van de besturen van het N.I.v.A. en de V.A.G.A. om de vermelding van de geaccumuleerde afschrijvingen voor elke in de balans onderscheiden groep vaste activa verplicht te stel$\left.\operatorname{len}^{19}\right)$ nict is gevolgd.

\section{Immateriële activa (artikel 11)}

Hier vinden wij de enige bindende waarderingsregel van het ontwerp, zij het dat alleen een bovengrens wordt aangegeven. De immateriële activa mogen namelijk ten hoogste worden gewaardeerd op het bedrag van de daaraan bestede kosten, verminderd met afschrijvingen.

In het ontwerp is de door de besturen van het N.I.v.A. en de V.A.G.A. voorgestelde redactic ${ }^{20}$ ) nagenoeg overgenomen, waardoor het niet meer aan twijfel onderhevig is - hetgeen bij de redactie van het voorontwerp wel het geval was dat het ook toegestaan is immateriële activa in het geheel niet in de balans op te nemen. Alleen voor zover deze activa wel worden opgenomen geldt voor de waardering derhalve genoemde bovengrens, terwijl dan de volgende posten moeten worden onderscheiden: goodwill, octrooien, licenties, auteursrechten, concessies en vergunningen, voorbereidings- en oprichtingskosten.

\section{Voorraden (artikel 16)}

Door een kleine redactiewijziging ten opzichte van het voorontwerp is aan de in dit artikel gegeven indeling het dwingende en limitatieve karakter ontnomen. Ook uit de Memorie van Toelichting blijkt dat de gegeven opsomming facultatief is bedoeld, de benaming en indeling van de posten mag derhalve aan de omstandigheden worden aangepast.

18) Zie het Advies van de S.E.R., blz. 12.

19) Zie de Accountant juli/augustus 1966, blz. 588/589.

20) Zie de Accountant juli/augustus 1966, blz. 589. 
Hiervoor geldt hetzelfde als voor de voorraden is opgemerkt, zij het dat op een andere plaats in het ontwerp (artikel 12, lid 3) dwingend is voorgeschreven dat vorderingen op ondernemingen waarin is deelgenomen afzonderlijk moeten worden vermeld.

Het wekt enige bevreemding dat, terwijl bij de schulden zorgvuldig onderscheid wordt gemaakt tussen het kortlopend en het langlopend gedeelte, een dergelijke aanwijzing bij de vorderingen geheel ontbreekt. Niettemin zal de algemene eis van artikel 2 met zich meebrengen, dat bij het bestaan van langlopende vorderingen van enige omvang deze met het oog op het inzicht in de liquiditeitspositie afzonderlijk van de andere vorderingen worden getoond.

Terloops zij nog vermeld dat de termen overlopend actief- en passiefposten in het ontwerp, zulks in tegenstclling tot het voorontwerp, niet meer voorkomen.

\section{Liquide middelen en fondsen (artikel 19)}

Van betekenis is de bepaling, dat moet worden aangegeven in hoeverre saldi bij banken- en giro-instellingen niet terstond opeisbaar zijn en in hoeverre dergelijke saldi, alsmede fondsen niet ter vrije beschikking van de onderneming staan. Dit laatste kan zich ten aanzien van fondsen bijvoorbeeld voordoen indien deze als zekerheid elders zijn gedeponeerd. De aloude onderscheiding tussen wel en niet aan een beurs genoteerde fondsen is vanzelfsprekend gehandhaafd. Het begrip beurs heeft echter een aanzienlijk ruimere inhoud gekregen dan in artikel 42 van het Wetboek van Koophandel (thans: ,enige Nederlandse of buitenlandse beurs").

\section{Eigen vermogen (artikelen 20 en 21)}

Nieuw is in vergelijking tot het voorontwerp de bepaling dat het eigen vermogen wordt onderscheiden in het geplaatste kapitaal (per soort aandelen, met gegevens omtrent storting) en de reserves (artikel 20, lid 1) en de reserves op hun beurt in groepen als agio-reserve, herwaarderingsreserve en ingehouden winst (artikel 20, lid 6).

Van betekenis achten wij de reeds in het voorontwerp opgenomen bepaling dat mededeling moet worden gedaan van de nominale waarde van de ingekochte, doch nict ingetrokken aandelen en van het bedrag waartegen zij in de balans zijn opgenomen. Zoals bekend mag worden verondersteld handelt een onderneming formeel niet in strijd met het huidige artikel 42 W.v.K. indien zij een dergelijk bezit onder de al of niet genoteerde fondsen opneemt, een presentatie die als regel een vertekend beeld van het eigen vermogen oplevert.

De verplichting tot het vermelden van de namen van houders van prioriteitsaandelen en dergelijke stukken, van het aantal dat elk hunner houdt en van de namen der bestuurders, zo die houder een rechtspersoon is, is ondanks het verzet van een meerderheid uit de S.E.R. gehandhaafd. Ook is de Minister niet ingegaan op de suggestie uit de S.E.R. om deze bepaling te beperken tot ondernemingen die niet tot publikatie verplicht zijn, waardoor aan de bepaling naar ons gevoelen overigens nagenoeg elke betekenis zou zijn ontnomen.

Wel is thans een ontsnappingsclausule opgenomen: de Minister van Economische 
Zaken kan (naar wij aannemen: telkens) voor ten hoogste vijf jaren wegens gewichtige belangen ontheffing van bedoelde verplichtingen verlenen.

Het beleid dat bij het verlenen van ontheffingen zal worden gevolgd, zal in hoge mate bepalend zijn voor de betekenis die de onderhavige vooorschriften zullen verkrijgen. Wij merken in dit verband op, dat men zou kunnen stellen dat het juist tegenover aandeelhouders in open naamloze vennootschappen noodzakelijk is dat geen twijfel wordt gelaten omtrent de personen die de verantwoordelijkheid voor de keuze van de leiding dragen.

\section{Schulden met een looptijd van meer dan een jaar (artikel 22)}

Hiervoor vinden wij weer een dwingende indeling in groepen, t.w. (gedeeltelijk in eigen bewoordingen): (a) obligatieleningen en pandbrieven, (b) schulden aan deelnemingen, (c) schulden aan groot-aandeelhouders en (d) overige schulden. Vermeld moet worden, behalve bij hypotheekbanken, het bedrag dat van deze schulden binnen een jaar na de balansdatum moet worden voldaan. In plaats van de enkele vermelding van dit bedrag verdient o.i. de voorkeur de procedure, waarbij het kortlopend gedeelte van de langlopende schulden daarop (zichtbaar) in mindering wordt gebracht en onder de kortlopende schulden wordt opgenomen. Deze procedure is ook volgens de Memorie van Toelichting niet met het genoemde voorschrift in strijd.

\section{Voorzieningen (artikel 23)}

Deze hebben, volgens de omschrijving in het wetsvoorstel, betrekking op risico's en verplichtingen, waarvan de omvang ten tijde van het opmaken van de balans nog niet nauwkeurig bekend is. In ieder geval zullen afzonderlijk moeten worden vermeld: (a) de voorzieningen die betrekking hebben op bepaalde activa, (b) de voorziening voor belastingverplichtingen welke na het bockjaar kunnen ontstaan en (c) de voorziening voor pensioenverplichtingen waarvoor de onderneming risico draagt. Deze opsomming is niet limitatief, men kan immers aan verschillende andere voorzieningen denken: voor garantieverplichtingen, voor survey van schepen, voor assurantie eigen risico, etc. Hoewel de laatstgenoemde twee voorzieningen, die in hoofdzaak een egalisatie van bepaalde lasten ten doel hebben, strikt genomen niet geheel aan de gegeven algemene omschrijving van voorzieningen voldoen, kunnen zij naar ons oordeel in deze rubriek toch een plaats vinden.

Een opmerking moet nog worden gemaakt over het voorschrift dat voorzieningen die betrekking hebben op bepaalde activa afzonderlijk moeten worden vermeld. De strekking van deze bepaling is naar onze mening uitsluitend deze, dat voorzieningen van deze aard die men, in plaats van deze als waarderingscorrectie van een actief af te trekken, onder de passiva zou willen opnemen, niet onder een of andere post onzichtbaar mogen worden gemaakt.

Het voorschrift laat dus o.i. geheel onverlet het juiste gebruik om voorzieningen die in feite waarderingscorrecties op activa voorstellen op de desbetreffende activa in mindering te brengen, integendeel, een juiste toepassing van de algemene bepaling uit artikel 5 zal daar veelal toe nopen.

De toelichting als bedoeld in artikel 42 van het Wetboek van Koophandel behoeft volgens de letter alleen betrekking te hebben op de activa. Nu de uiteenzetting 
omtrent de grondslagen van waardering die artikel 5, lid 2 van het wetsvoorstel verlangt zowel de activa als de passiva dient te omvatten, zal ook ten aanzien van de hier bedoelde voorzieningen een uiteenzetting moeten worden gegeven over de wijze waarop zij zijn bepaald. Hier kunnen immers verschillende waarderingsvraagstukken liggen.

Een belangrijke uitzondering is gemaakt op het voorschrift om bepaalde voorzieningen afzonderlijk te tonen en wel ten aanzien van een voorziening voor het algemeen risico dat voor kredietinstellingen, spaarbanken en hypotheekbanken voortspruit uit de verlening van kredieten en uit het overige actieve bankbedrijf (artikel 23, lid 3). Let wel, het gaat hier dus niet om specifieke voorzieningen tegenover aanwijsbaar dubieuze posten, deze zullen als waarderingscorrectie op het bedrag van de vorderingen in mindering moeten worden gebracht. Bedoclde instellingen behoeven de omvang van een dergelijke algemene voorziening derhalve niet te publiceren, wel zullen bedragen die daaraan ten laste of ten gunste van de winst-en verliesrekening worden toegevoegd of onttrokken afzonderlijk moeten worden aangegeven.

\section{Schulden met cen looptijd korter dan een jaar (artikel 24)}

Ten aanzien van de wijze van indeling van deze schulden is men tot op zekere hoogte vrij. Alleen zullen, indien zij voorkomen, afzonderlijk moeten worden vermeld banklkredieten, schulden aan leveranciers, handelskredieten, schulden ter zaken van pensioenen en belastingschulden.

\section{Diverse te verstrekken gegevens}

Ter informatie volgt tenslotte nog een opsomming van gegevens die in de balans of in de toelichting daarop moeten worden vermeld, voor zover die niet in het voorgaande of in paragraaf $\mathrm{V}$ (Deelnemingen) worden behandeld.

(a) Melding moet worden gemaakt van het obligo ter zake van verdisconteerde wissels (artikel 18), waardoor de omvang van het totale debiteurenrisico dat op de balansdatum werd gelopen tot uitdrukking komt.

(b) Het aantal in omloop zijnde oprichtingsbewijzen, winstbewijzen en dergelijke stukken moet per soort worden medegedeeld (artikel 21).

(c) Aangegeven moet worden voor welke groepen van schulden zekerheid is gesteld en in welke vorm dit is geschied, alsmede ten aanzien van welke groepen van schulden de onderneming zich heeft verbonden haar goederen niet te bezwaren.

Gold deze in artikel 22, lid 2 geformuleerde bepaling in het voorontwerp alleen voor langlopende schulden, in het wetsvoorstel is zij door verwijzingen voor alle schulden toepasselijk verklaard. Dit betekent derhalve dat, indien b.v. ter zake van een bankkrediet voorraden in fiduciaire eigendom zijn overgedragen of vorderingen zijn gecedeerd, daarvan mededeling moet worden gedaan.

(d) Van leningen moeten, behalve bij hypotheekbanken, het rentepercentage en het nog niet verstreken gedeelte van de looptijd worden vermeld; van converteerbare leningen bovendien de voorwaarden van conversie (artikel 22, leden 3 en 4$)$. 
(e) Mededeling moet worden gedaan, met aanduiding van de financiële consequenties:

- van het bestaan van - belangrijke - overeenkomsten waardoor gedurende een aantal jaren beslag wordt gelegd op een vast gedeelte van het inkomen van de vennootschap (b.v. huur-, pacht- en charterovercenkomsten etc., zie artikel 25);

- van financiële verplichtingen die door hun aard of omvang van bijzondere betekenis zijn, zoals belangrijke bestellingen, die niet uit de normale bedrijfsuitoefening voorvloeien (artikel 25);

- voorwaardelijke verplichtingen, voortvloeiende uit verstrekte garanties, borgtochten etc. (artikel 26).

(f) Tenslotte moet - op grond van het bestaande artikel $40 \mathrm{c}$ W.v.K., dat door de onderhavige wet niet zal worden gewijzigd - van met name genoemde overeenkomsten die na de oprichting van een naamloze vennootschap worden aangegaan, de zakelijke inhoud worden opgenomen in de toclichting op de jaarrekening over het boekjaar waarin de overeenkomst tot stand is gekomen. Het gaat hier om overeenkomsten:

- in verband staande met het nemen van aandelen, waarbij bijzondere verplichtingen op de vennootschap worden gelegd:

- rakende het verkrijgen van aandelen op andere voet dan waarop de deelneming in de naamloze vennootschap voor het publiek wordt opengesteld;

- strekkende om enigerlei voordeel te verzekeren aan cen oprichter of aan een bij de oprichting betrokken derde;

- betreffende de storting op aandelen op andere wijze dan door betaling van Nederlands wettig betaalmiddel.

\section{De pyinst- en verliesrekening met de toelichting}

Naar analogie met hetgeen voor de balans is bepaald geldt voor de winst- en verliesrekening met de toelichting, dat deze getrouw en stelselmatig de grootte en de samenstelling van het resultaat over het bockjaar dient weer te geven (artikel 3, lid 2); ook hier mogen de te verstrekken gegevens hetzij in de winst- en verliesrekening zelf, hetzij in de toelichting worden opgenomen (artikel 27).

De winst- en verliesrekening dient inzicht te geven in de omvang van de zaken en in de gang van zaken van de onderneming gedurende het verstreken jaar.

Het inzicht in de omvang van de zaken wordt gegeven volgens voor de betrokken bedrijfstak aanvaardbare maatstaven (artikel 28). Indien men niet zover wil gaan om de omzet zelf, hetzij in geld dan wel in hoeveelheden, te vermelden, mogen ook verhoudingscijfers worden gebezigd ten opzichte van het voorafgaande boekjaar. De Minister heeft deze tegemoetkoming in vergelijking tot de voorschriften in andere landen (b.v. Duitsland, Engeland) opgenomen, omdat hij van mening is dat het belang van aandeelhouders en andere belanghebbenden - behalve concurrenten - voldoende is gediend met het geven van inzicht in de ontwikkeling van de omzet. Om de positie van een bedrijf ook uit een andere gezichtshoek te doen belichten, is voorts bepaald dat het bedrag van de lonen en sociale lasten over het boekjaar moet worden vermeld. 
Artikel 29, lid 1, dat nagenoeg geheel in overeenstemming is met een voorstel dat door de S.E.R. is gedaan en door de besturen van het N.I.v.A. en V.A.G.A. is ondersteund, zegt dat ten aanzien van de gang van zaken inzicht wordt gegeven door vermelding van (a) het bedrijfsresultaat, (b) de overige baten en lasten, (c) de winst of het verlies vóór belastingen en (d) het geschatte bedrag voor belastingen met betrekking tot de winst. De genoemde gegevens, in het bijzonder uiteraard het bedrijfsresultaat, moeten nader worden gesplitst en toegelicht volgens voor de betrokken bedrijfstak aanvaardbare maatstaven. Het tweede lid van genoemd artikel geeft vervolgens een opsomming van posten die afzonderlijk moeten worden vermeld.

Bij dit alles is het niet verplicht gesteld, zoals de S.E.R. had gesuggereerd, vergelijkende cijfers van het voorafgaande boekjaar op te nemen. Voor een wettelijke verplichting ter zake ontbreekt volgens de Memorie van Toelichting voldoende grond; het vermelden van de cijfers van het vorige jaar zonder de daarbij behorende toelichting zou geen bevredigend vergelijkingsmateriaal bieden. Hoewel uit een oogpunt van wetsconstructie dit standpunt begrijpelijk is, neemt dit niet weg dat hoezeer de betekenis daarvan ook beperkt is - een goede verslaggeving als regel toch met het opnemen van vergelijkende cijfers zal zijn gediend. Ook de Memorie van Toelichting laat daarover geen twijfel bestaan. Daarbij zal het meestal noodzakelijk zijn dat, wanneer de toelichting in het vorige jaarverslag een mededeling bevatte die tot goed begrip van de cijfers over dat jaar onontbeerlijk was, zodanige mededeling bij de vergelijkende cijfers in een of andere vorm wordt herhaald. Intussen mag overigens worden geconstateerd dat zeer vele ondernemingen in hun jaarverslagen reeds vergelijkende cijfers opnemen.

De Sociaal-Economische Raad verwacht, en de Minister meent blijkens zijn toelichting dat deze verwachting terecht wordt gekoesterd, dat door het volgen van het hiervoor gegeven zeer algemene schema de onderlinge vergelijkbaarheid van winst- en verliesrekeningen zal worden bevorderd en een analyse der gegevens zal worden vergemakkelijkt. Dit moge op zichzelf juist zijn, toch zij men voorzichtig met het trekken van conclusies bij het vergelijken van cijfers uit winst- en verliesrekeningen van verschillende bedrijven. Door de onderwerpelijke bepalingen zal weliswaar een zekere overeenstemming in de vorm van presentatie worden bereikt, ter zake van de inhoud van de cijfers kunnen echter grote afwijkingen bestaan, welke voor cen belangrijk deel hun oorzaak vinden in de nu eenmaal voorkomende grote verschillen in de dynamiek van de leiding der ondernemingen.

Uit het voorgaande blijkt overigens wel dat bij de opzet van de winst- en verliesrekening aan het bedrijfsleven een grote mate van vrijheid wordt gelaten, waarbij echter moet worden bedacht, dat de algemene eis van artikel 2 (er moet een verantwoord oordeel kunnen worden gevormd omtrent het resultaat) altijd op de achtergrond staat.

Een dwingende verplichting tot het afzonderlijk vermelden van bepaalde baten en lasten geeft alleen nog her tweede lid van artikel 29, waarin als zodanig worden opgesomd (a) de afschrijvingen op vaste activa, (b) de afschrijvingen op immateriële activa, (c) de winsten of verliezen uit deelnemingen, (d) de winsten of verliezen uit beleggingen, (e) de rentebaten, ( $\mathrm{f}$ ) de rentelasten, $(\mathrm{g})$ de buitengewone baten en (h) de buitengewone lasten. Een dergelijke, doch aanzienlijk kortere op-

m a b blz. 311 
somming kwam ook in het voorontwerp-Verdam voor. $\mathrm{Bij}$ enkele der genoemde posten plaatsen wij nog een korte kanttekening.

\section{Winsten of verliezen uit deelnemingen}

Onder dit hoofd kunnen, al naar gelang het verantwoordingssysteem dat men ter zake hantecrt, of wel de dividenden worden opgenomen, of wel het evenredig aandeel in de resultaten van de deelnemingen. Winsten of verliezen bij het afstoten van deelnemingen zullen vermoedelijk veelal als een buitengewone bate of last moeten worden aangemerkt.

\section{Rentebaten en -lasten}

Strikt genomen mogen de rentebaten en -lasten niet worden gesaldeerd, hetgeen niet wegneemt dat het wel mogelijk is in de winst- en verliesrekening een saldopost op te nemen met ontleding in de toelichting. Het is naar onze mening ook toegestaan in de winst- en verliesrekening zelf geen afzonderlijke rentepost op te nemen, doch in de toelichting te vermelden welke rentebaten en -lasten in de cijfers zijn verwerkt.

\section{Buitengewone baten en -lasten}

Ter zake van een saldering van buitengewone baten en -lasten geldt hetzelfde als t.a.v. de rente is opgemerkt. Wel zal het inzicht dat de winst- en verliesrekening behoort te geven veelal met zich mee brengen, dat dergelijke posten - eventueel gesaldeerd - afzonderlijk in de winst- en verliesrekening zelf moeten worden getoond. De beoordeling van de vraag of van een buitengewone bate of -last sprake is wordt aan het subjectieve inzicht van de samenstellers van een jaarrekening overgelaten, waarbij de accountant die bij die jaarrekening cen verklaring moet afgeven uiteraard zijn eigen subjectieve inzicht heeft. Hier ligt een terrein waar een aantal algemene richtlijnen te verstrekken door een commissie als in paragraaf I bedoeld, bepaald nuttig zouden kunnen werken. Persoonlijk zouden wij willen zeggen dat er van een buitengewone bate of -last sprake is, indien zich een post van belangrijke omvang voordoet die, hetzij naar zijn aard niet is ontstaan uit de normale bedrijfsactiviteiten van de onderneming, hetzij betrekking heeft op transacties of gebeurtenissen die zich in een voorgaande periode hebben voorgedaan en waarvan de financiële gevolgen destijds niet met een redelijke mate van zekerheid konden worden vastgesteld. ${ }^{21}$ ) In dit verband moge worden aangetekend dat in de Verenigde Staten uitdrukkelijk onderscheid wordt gemaakt tussen eerstbedoelde ,extraordinary items” en laatstbedoelde ,prior period adjustments”, voor welke groepen van posten ook een verschillende wijze van verantwoording moet worden toegepast. Het zou ons te ver voeren op de betekenis en achtergrond van deze onderscheiding in dit artikel verder in te gaan; de belangstellende lezer zij verwezen naar Opinion No. 9 van de Accounting Principles Board ${ }^{22}$ ). Wel willen wij nog melding maken van een ander gebruik in de Verenigde Staten, en wel om de buitengewone baten en -lasten op nettobasis te tonen, d.w.z. na aftrek van het daaraan toe te rekenen gedeelte van de belasting met betrekking tot de winst. Dit gebruik verdient naar onze mening stellig navolging; een presentatie

${ }^{21}$ ) Zie J. A. Burggraaff, Presentatie van belasting naar de winst in de resultatenrekening (MAB, maart 1968).

$\left.{ }^{22}\right)$ Publikatie van het American Institute of Certified Public Accountants, december 1966. 
op deze wijze, mits duidelijk toegelicht, is onder de wet op de jaarrekening o.i. zeer wel mogelijk.

Evenals aan het slot van paragraaf III ten aanzien van de balans is geschied, volgt hierna nog een opsomming van gegevens die in de winst- en verliesrekening of in de toelichting daarop moeten worden opgenomen, voorzover die in het voorafgaande nog niet zijn behandeld.

(a) De bestemming van de winst of de verwerking van het verlies moet worden aangegeven, met vermelding van de statutaire bepalingen dienaangaande (artikel 8).

(b) Het bedrag der bezoldigingen van commissarissen gezamenlijk moet worden vermeld, zulks in tegenstelling tot hetgeen in het voorontwerp-Verdam was gesteld, namelijk de vermelding van de bezoldiging van ieder der commissarissen. Wel moet het totale bedrag gesplitst worden in vaste beloningen, tantièmes en andere vormen van bezoldiging en moet worden vermeld of de belasting op deze bezoldigingen ten laste van de onderneming komt. Tenslotte moet melding worden gemaakt van het aantal commissarissen en van het aantal van degenen onder hen die geen bezoldiging ontvangen. Deze bepaling van artikel 7 is in zijn opzet geheel in overeenstemming met hetgeen op dit terrein door de S.E.R. is voorgesteld.23)

\section{Deelnemingen}

In het ontwerp is een relatief grote plaats ingeruimd voor het regelen van verschillende aspecten van de verslaggeving, die betrekking hebben op het houden van deelnemingen

Een definitie van het begrip ,deelneming" is niet gegeven; in de opzet van het wetsvoorstel is aan een zodanige definitie ook nauwelijks of geen behoefte. Voor participaties - rechtstreeks of middellijk - van $25 \%$ of meer in het geplaatste kapitaal van een onderneming heeft men namelijk geen twijfel willen laten bestaan: een zodanige participatie wordt in ieder geval als een deelneming beschouwd (artikel 12, lid 1). Het begrip ,onderneming” in de vorige zin is daarbij niet beperkt tot de ondernemingen in de zin der wet, zodat ook participaties in Nederlandse bedrijven die geen onderneming in de zin der wet zijn (b.v. vennootschappen onder firma) en participaties in buitenlandse bedrijven een deelneming kunnen uitmaken (artikel 15, lid 1).

Door de bepaling dat een participatie van $25 \%$ of meer in ieder geval als een deelneming moet worden aangemerkt, is voor dergelijke participaties elk ander criterium dat zou kunnen worden gehanteerd bij de beoordeling van de vraag of van een deelneming sprake is uitgeschakeld. Wij denken hier met name aan de volgende door de besturen van het N.I.v.A. en de V.A.G.A. genoemde mogelijke criteria $\left.{ }^{24}\right)$ :

a. de investering dient te passen in het kader van de onderneming;

b. zij dient niet van tijdelijke aard te zijn;

c. zij moet in het kader van de onderneming van betekenis zijn.

23) Zie Advies van de S.E.R., blz. 11.

24) Zie de Accountant van juli/augustus 1966, blz. 589/590. 
Een door de genoemde besturen aanbevolen uitbreiding van lid 1 van artikel 12 met ,tenzij dit bezit van tijdelijke aard is of niet past in het kader van de deelnemende onderneming", waarmede recht zou zijn gedaan aan de criteria sub a en b, is in het ontwerp niet overgenomen. Een dergelijk voorstel van een uit een groot aantal leden bestaande minderheid van de S.E.R. ${ }^{25}$ ) heeft evenmin tot een wijziging van het wetsvoorstel geleid. Het is duidelijk dat de Minister van mening is dat daardoor teveel subjectieve elementen zouden worden geïntroduceerd. Een en ander brengt voor de praktijk met zich mede, dat men genoemde criteria alleen een rol zou kunnen laten spelen als het gaat om participaties van minder dan $25 \%$.

Al naar gelang de eisen die ten aanzien van de te verstrekken financiële informatie worden gesteld, kunnen de deelnemingen in drie groepen worden ingedeeld:

(a) deelnemingen - rechtstreeks of middellijk - voor niet meer dan de belft van het geplaatst kapitaal;

(b) binnenlandse deelnemingen - rechtstreeks of middellijk - voor meer dan de belft van het geplaatst kapitaal;

(c) buitenlandse deelnemingen - rechtstreeks of middellijk - voor meer dan de belft van het geplaatst kapitaal.

De aandacht wordt erop gevestigd dat in het ontwerp als maatstaf voor het belang uitsluitend het criterium ,geplaatst kapitaal" wordt gehanteerd. Aan een tweede criterium, dat in de praktijk wel afzonderlijk wordt aangelegd, namelijk „de mogelijkheid om de meerderheid van het stemrecht te kunnen (doen) uitoefenen" is in de structuur van het ontwerp geen behoefte, het is impliciet van toepassing. Ter verduidelijking het volgende voorbeeld: Stel dat onderneming A een belang van $60 \%$ heeft in onderneming $B$, en onderneming $B$ op haar beurt een belang van $60 \%$ in onderneming $\mathrm{C}$. Het is dan zonder meer duidelijk dat onderneming $B$ moet worden geklasseerd onder de hiervoor omschreven rubrieken (b) of (c), al naar gelang het een binnen- of een buitenlandse onderneming betreft. In onderneming $C$ heeft $A$ een (indirect) belang van slechts $36 \%$, echter kan onderneming A, doordat zij de zeggenschap in onderneming $B$ heef $t$, in feite beslissen over de stemmen die op $60 \%$ van de aandelen in $\mathrm{C}$ zullen worden uitgebracht.

Door de bepaling in de eerste zin van het eerste lid van artikel 13 worden voor de verslaggeving van $A$ ten aanzien van de met betrekking tot $C$ te verstrekken informatie niettemin dezelfde eisen gesteld als ware het een meerderheidsdeelneming. Bedoelde bepaling luidt: ,omtrent de ondernemingen waarin de onderneming rechtstreeks of middellijk voor meer dan de helft van het geplaatst kapitaal deelneemt, worden zo getrouw mogelijk alle inlichtingen verstrekt, die krachtens deze wet in de jaarrekening moeten voorkomen". Welnu, omtrent onderneming $\mathrm{B}$ uit ons voorbeeld moeten dus alle inlichtingen die krachtens de wet in de jaarrekening moeten voorkomen worden verschaft. Met andere woorden: op de voor onderneming $B$ te verstrekken informatie is de gebele wet, inclusief artikel 13, lid 1 zelf, van toepassing en dus zullen ook omtrent een meerderheidsdeelneming van $B$, met name dus ten aanzien van onderneming $C$, alle inlichtingen moeten worden verstrekt, die krachtens de wet in een jaarrekening moeten voorkomen.

25) Zie Advies van de S.E.R., blz. 14.

$\mathrm{m}$ a b blz. 314 
Op de aard van de te verstrekken financiële informatie zullen wij nu voor elk van de hierboven genoemde drie categorieën deelnemingen wat nader ingaan.

\section{Deelnemingen voor niet meer dan de belft van bet geplaatst kapitaal}

Voor deze categorie moeten zo getrouw mogelijk inlichtingen worden verstrekt over de waarde, alsmede omtrent de wijzigingen in die waarde gedurende het afgelopen boekjaar (artikel 12, lid 1). Van die wijzigingen moet af zonderlijk worden vermeld het bedrag van de wijziging die voortvloeit uit de resultaten van de deelnemingen (artikel 12, lid 2). Uit de tekst van deze bepaling, als ook uit de Memorie van Toelichting, kan worden afgeleid dat ermede kan worden volstaan de bedoelde gegevens voor alle deelnemingen uit deze categorie gezamenlijk te verstrekken.

Ten aanzien van vorenbedoelde waarde is het denkbaar dat deze tevens het bedrag zal uitmaken waarvoor de desbetreffende deelnemingen in de balans worden opgenomen. Het is ook mogelijk dat in de balans b.v. slechts de kostprijs van de deelnemingen wordt verwerkt en dat de toelichting op de balans gegevens omtrent bedoelde waarde zal bevatten. In beide gevallen zal het noodzakelijk zijn in de toelichting aan te geven welke grondslagen bij het bepalen der waarde zijn gehanteerd, welke grondslagen uiteraard wederom zullen moeten voldoen aan normen die in het maatschappelijk verkeer als aanvaardbaar worden beschouwd.

Door verschillende oorzaken kan de waarde van het belang in een deelneming wijzigingen ondergaan, zoals door winst of verlies van de deelneming, door kapitaalstortingen of -terugbetalingen, door herwaarderingen en uitkering van dividend. Het ligt voor de hand dat wordt verlangd, dat van die verschillende factoren tenminste het evenredig aandeel in het nettoresultaat van de deelneming afzonderlijk wordt genoemd. De eis van het getrouwe inzicht in het resultaat brengt naar ons oordeel met zich mede, dat aan deze vermelding een toelichting wordt toegevoegd, indien zich bij de deelnemingen buitengewone baten of lasten van enige importantie hebben voorgedaan.

\section{Binnenlandse deelnemingen voor meer dan de helft van bet geplaatst kapitaal}

Dit zijn de deelnemingen met betrekking waartoe, zoals reeds eerder vermeld, zo getrouw mogelijk alle inlichtingen moeten worden verstrekt die krachtens de wet in een jaarrekening moeten voorkomen (artikel 13, lid 1). Ook in dit geval kunnen die inlichtingen voor alle deelnemingen uit deze categorie desgewenst worden samengevoegd, hetgeen hieruit blijkt, dat men aan de genoemde eis kan voldoen door overlegging van:

- hetzij cen geconsolideerde jaarrekening;

- hetzij een samengevoegde jaarrekening van de betrokken deelnemingen of samengevoegde jaarrekeningen van afzonderlijk te onderscheiden groepen in de betrokken deelnemingen;

- hetzij afzonderlijke jaarrekeningen van de betrokken deelnemingen.

Het is interessant hierbij aan te tekenen, dat de desbetreffende bepaling de bedoclde geconsolideerde, samengevoegde of afzonderlijke jaarrekeningen uitdrukkelijk tot onderdeel van de toelichting bestempelt.

Dit behoeft naar ons oordeel geenszins te betekenen dat de onderneming, die de 
gewoonte heeft in haar jaarverslag de geconsolideerde jaarrekening als hoofdschotel voorop te stellen, nu met deze traditie moet breken. Evenmin behoeft het vorenstaande er o.i. toe te leiden, dat de accountant nu persé de geconsolideerde jaarrekening in zijn verklaring bij de juridische jaarrekening behoort te betrekken; het zal hem, indien hij dat wenst, naar onze mening ook in de toekomst zijn toegestaan bij die geconsolideerde jaarrekening een afzonderlijke verklaring te verstrekken. Het gaat hier immers slechts om vormkwesties, waardoor aan de grondbeginselen van de wet geen enkele afbreuk wordt gedaan. Wel brengt het systeem van de wet met zich mede dat een goedkeurende verklaring bij een juridische jaarrekening, indien het desbetreffende verslag tevens een geconsolideerde jaarrekening bevat waaromtrent door de accountant niets wordt gezegd, nochtans impliciet de goedkeuring van de geconsolideerde jaarrekening geacht zal worden in te houden.

Zoals reeds gezegd: voor deze categorie van deelnemingen moeten alle inlichtingen worden verstrekt die krachtens de wet in een jaarrekening moeten voorkomen. Dit impliceert dat vorenbedoelde geconsolideerde, samengevoegde of af zonderlijke jaarrekeningen, voor zover van toepassing, aan de bepalingen van de wet moeten voldoen, èn aan de algemene bepalingen van hoofdstuk I, èn aan de specifieke bepalingen voor balans en winst- en verliesrekening in de hoofdstukken II en III. Dit betekent tevens, dat hetgeen in dit artikel in de paragrafen III en IV is opgemerkt, mutatis mutandis op bedoelde jaarrekeningen van toepassing is.

\section{Buitenlandse deelnemingen voor meer dan de belft van het geplaatst kapitaal}

Het ontwerp maakt in eerste instantie - namelijk in artikel 13 - geen onderscheid tussen binnen- en buitenlandse meerderheidsdeelnemingen, zodat men, indien de gegevens daartoe beschikbaar zijn, de informatie omtrent deze buitenlandse deelnemingen desgewenst op dezelfde wijze en gecombineerd met de informatie omtrent binnenlandse meerderheidsdeelnemingen kan verschaffen. Met andere woorden: de geconsolideerde jaarrekening behoeft niet beperkt te blijven tot de binnenlandse deelnemingen. Integendeel, uit het ontwerp en de Memorie van Toelichting kan duidelijke voorkeur voor een alle meerderheidsdeelnemingen omvattende geconsolideerde jaarrekening worden afgeleid. Niettemin blijkt uit het ontwerp, dat men bij de samenstelling een open oog heeft gehad voor de moeilijkheden die kunnen zijn verbonden aan het consolideren van buitenlandse deelnemingen of zelfs aan het verschaffen van dié inlichtingen omtrent een buitenlandse deelneming, die krachtens de wet in een jaarrekening moeten voorkomen. Bedoelde moeilijkheden kunnen bestaan uit andere groeperingen van posten, andere waarderingsgrondslagen, noodzakelijke omrekeningen, enz. In het ontwerp is daarom in artikel 15, lid 2 aangegeven op welke twee manieren met betrekking tot die deenemingen ook aan de voorschriften van artikel $13 \mathrm{kan}$ worden voldaan, t.w.:

- door de laatste jaarrekening van de betrokken deelnemingen, opgemaakt volgens voorschrift van het toepasselijk buitenlands recht, al dan niet samengevoegd in de toelichting van de jaarrekening op te nemen of

- zodanige stukken ter inzage van een ieder ten kantore van het handelsregister neder te leggen en in de toelichting naar deze nederlegging te verwijzen.

Een bepaling welke o.i. van grote realiteitszin getuigt. 
Er zijn nog drie bepalingen, waarop wij de aandacht willen vestigen, die voor ondernemingen die deel uitmaken van cen groep van ondernemingen van bijzondere betekenis kunnen zijn. Géén van deze bepalingen $\mathrm{kwam}$ in het voorontwerpVerdam voor. Hoewel hetgeen thans is gecodificeerd misschien met enige goede wil, althans gedeeltelijk, wel uit dat voorontwerp kon worden afgeleid, achten wij het toch een gelukkige omstandigheid dat bedoelde bepalingen thans expliciet zijn opgenomen. Wij denken hier aan de bepalingen uit artikel 13, lid 2, artikel 13, lid 3 en artikel 30 van het ontwerp.

Artikel 13, lid 2 heeft betrekking op de onderneming B, die meerderheidsdeelnemingen bezit en waarvan het gehele geplaatste kapitaal, direct of indirect, door een andere onderneming $\mathrm{A}$ wordt gehouden. Indien $\mathrm{A}$ reeds an het voorschrift van artikel 13, lid 1 voldoet, bijvoorbeeld door overlegging van een geconsolideerde jaarrekening, is $B$ van de verplichting tot overlegging van een zodanige jaarrekening ontslagen. Dit is een alleszins doelmatige bepaling, waardoor wordt voorkomen dat uitsluitend op grond van formele voorschriften een geconsolideerde jaarrekening voor een deel van een groep ondernemingen zou moeten worden opgesteld, waarmede in de meeste gevallen vermoedelijk geen enkel rationeel doel zou worden gediend. Aangetckend wordt dat genoemd artikel voor onderneming $B$ geen ontheffing van de voorschriften uit het eerste en tweede lid van artikel 12 inhoudt, zodat zij niettemin gehouden is omtrent de (gezamenlijke) waarde van haar deelnemingen en omtrent de wijzigingen van deze waarde zo getrouw mogelijk inlichtingen te verstrekken.

Artikel 13, lid 3 heeft betrekking op de onderneming $\mathrm{D}$, waarvan de gegevens ingevolge artikel 13, lid 1 in de jaarrekening van een onderneming $C$ worden opgenomen en die haar jaarrekening niet ten kantore van het handelsregister behoeft neder te leggen (zie paragraaf II, publikatieplicht).

Indien alle aandeelhouders of leden van $\mathrm{D}$ daarmede vóór de afloop van het boekjaar hebben ingestemd, behoeft $\mathrm{D}$ zijn jaarrekening niet volgens de eisen van de wet in te richten. Ook dit is een rationele bepaling. Indien geen der aandeelhouders van een dergelijke besloten onderneming daaraan behoef te heeft, kan een detaillering van de jaarrekening overeenkomstig de eisen der wet immers zonder aantasting van enig belang achterwege blijven.

Het is vanzelfsprekend dat de hier besproken ontheffingsmogelijkheid niet kan gelden, wanneer voor de betrokken vennootschap een publikatieplicht bestaat. Indien bijvoorbeeld een obligatielening uitstaat, heeft de jaarrekening van die vennootschap voor obligatiehouders een zelfstandige betekenis en het zou niet juist zijn de eisen omtrent de inrichting van de jaarrekening in een dergelijk geval niet van toepassing te verklaren. Voor een dergelijke beperking heeft men blijkbaar bij de ontheffingsmogelijkheid uit artikel 13, lid 2, die hiervoor werd besproken, geen aanleiding gevonden.

Artikel 30 heeft tenslotte betrekking op de eigen winst- en verliesrekening van een onderneming, die overeenkomstig artikel 13, lid 1 tevens een geconsolideerde jaarrekening in de toelichting opneemt. Zodanige onderneming is gerechtigd desgewenst elke specificatie in de eigen - juridische - winst- en verliesrekening achter- 
wege te laten, voor zover de geconsolideerde winst- en verliesrekening met de toelichting aan de bepalingen van de artikelen 28 en 29 voldoet.

Wij achten dit een voor het bedrijfsleven bijzonder nuttige bepaling, die met name van belang is voor een houdstermaatschappij, die zelf ook een bedrijf uitoefent. De topleiding van een dergelijke maatschappij behoeft zich daardoor bij bepaalde beslissingen geen zorgen te maken over de vraag in welke van de tor de groep behorende ondernemingen de resultaten van die beslissingen hun neerslag zullen vinden, omdat alleen het geconsolideerde resultaat van die ondernemingen gedetailleerd naar buiten behoeft te worden gebracht.

Er wordt op gewezen dat een analoge bepaling ten aanzien van de balans niet is opgenomen. De - juridische - balans dient dus aan alle bepalingen van de wet te voldoen, ook indien de toelichting tevens een geconsolideerde balans bevat. Dit is een volkomen logische zaak. Crediteuren kunnen zich immers over de liquiditeits- en solvabiliteitspositie van een onderneming waarmede zij een financiële relatie hebben alleen uit de juridische balans een oordeel vormen. Indien de juridische balans in een geconsolideerde balans is opgegaan, zal die oordeelsvorming in de meeste gevallen niet meer mogelijk zijn. In plaats van meer inzicht te geven kan een geconsolideerde balans onder bepaalde omstandigheden juist op de genoemde punten het beeld wel eens vertroebelen.

Aan één onderwerp met betrekking tot deelnemingen is tot dusverre nog geen aandacht besteed, en wel aan de vermelding der namen van deelnemingen in de jaarrekening. De S.E.R. heeft voor een zodanige vermelding, althans voor meerderheidsdeelnemingen, een warm pleidooi gevoerd $\left.{ }^{2}{ }^{2}\right)$, zij het dat naar het oordeel van de S.E.R. bij voldoende gewichtige ondernemingsbelangen wel een ontheffingsmogelijkheid aanwezig moet zijn. Aan het verlangen van de S.E.R. is voldaan. Deze materie, waarover het voorontwerp-Verdam geen voorschriften bevatte, is thans geregeld in artikel 14 van het ontwerp. De namen van de, directe en/of indirecte, meerderheidsdeelnemingen moeten, met vermelding van hun zetel:

- hetzij in de jaarrekening worden genoemd (de toelichting zal daarvoor de aangewezen plaats zijn);

- hetzij in een lijst worden opgenomen, die bij het handelsregister wordt gedeponeerd, naar welke lijst in de jaarrekening wordt verwezen.

Deze verplichting geldt zowel voor binnen- als buitenlandse meerderheidsdeelnemingen. Het is naar onze mening niet geheel duidelijk of een onderneming met meerderheidsdeelnemingen, waarvan de cijfers in een geconsolideerde jaarrekening van een andere onderneming worden opgenomen en die onder bepaalde omstandigheden haar jaarrekening niet volgens de eisen van de wet behoeft in te richten, daarmede ook van de verplichting tot vermelding van de namen van haar meerderheidsdeelnemingen is ontslagen. Het lijkt voor de hand liggend dat dit wel de bedoeling moet zijn.

Een door de S.E.R. gewenste ontheffingsmogelijkheid van bedoelde verplichting is, zij het op enigszins andere wijze dan door de S.E.R. voorgesteld, tevens in het ontwerp opgenomen. In twee gevallen mag de vermelding van de namen van meerderheidsdeelnemingen achterwege blijven, t.w.:

26) Zie Advies van de S.E.R., blz. 15-17.

$\mathrm{m}$ a b blz. 318 
- voor zover de gezamenlijke activa van de niet met name vermelde ondernemingen niet meer bedragen dan $15 \%$ van het totaal der activa op consolidatie basis;

- voor zover de Minister van Economische Zaken aan de onderneming op haar verzoek wegens gewichtige belangen ontheffing van bedoelde verplichting heeft verleend. Ingeval het een verzekeringsonderneming betreft, zal de Minister een zodanige beslissing niet geven alsvorens de Verzekeringskamer te hebben gehoord (artikel 36, lid 3).

Laatstbedoelde ontheffing kan - naar wij aannemen telkens - voor één jaar of voor een aantal opeenvolgende jaren met een maximum van vijf jaren worden gegeven. Indien een onderneming op grond van deze ontheffingsmogelijkheden vermelding van de naam van een of meer ondernemingen achterwege heeft gelaten, moet zulks in haar jaarrekening worden vermeld.

\section{Rechtspleging inzake jaarrekeningen}

De wetgever heeft op het punt van de rechtspleging inzake jaarrekeningen de voorstellen van de Commissie-Verdam nagenoeg ongewijzigd overgenomen. De artikelen $31 \mathrm{t} / \mathrm{m} 35$ van het ontwerp zijn dan ook bijna woordelijk gelijk aan de artikelen $27 \mathrm{t} / \mathrm{m} 31$ uit het voorontwerp, met uitzondering van de volgende aanvullingen:

1) De termijn waarbinnen een rechtsvordering kan worden ingesteld (normaliter binnen twee maanden na de vaststelling of goedkeuring van de jaarrekening), eindigt met betrekking tot rechtsvorderingen omtrent stukken die ten kantore van het handelsregister moeten worden neergelegd eerst nadat twee maanden sedert de dag der nederlegging zijn verstreken;

2) de dagvaarding moet aangeven in welk opzicht de jaarrekening herziening behoeft;

3) een zaak betreffende een jaarrekening wordt met gesloten deuren behandeld; het vonnis wordt in het openbaar uitgesproken;

4) de ondernemingskamer beslist niet dan nadat zij de betrokken deskundige heeft gehoord, althans ten verhoor heeft opgeroepen;

5) op een verzoek van een onderneming om een eerder gegeven bevel wegens wijziging van omstandigheden in te trekken wordt niet beslist dan na verhoor, althans behoorlijke oproeping van degene op wiens vordering het eerdere bevel is gegeven.

Voorts is elders in het ontwerp bepaald (artikel 36, lid 2), dat de ondernemingskamer ten aanzien van een verzekeringsonderneming geen beslissing geef $t$ zonder de Verzekeringskamer in de gelegenheid te hebben gesteld ter zake te worden gehoord.

Deze aanvullingen spreken o.i. voor zichzelf; aangetekend wordt, dat met de aanvulling sub 4) geheel voldaan is aan de wens die door de besturen van het N.I.v.A. en de V.A.G.A. in hun gezamenlijke brief van 8 maart 1967 aan de Minister van Justitie ${ }^{27}$ ) naar voren is gebracht.

27) Gepubliceerd in de Accountant van maart 1967, blz. 321 en 322. 
Door de volledige aanvaarding van de betrokken voorstellen van de CommissieVerdam door de Minister van Justitie (in de Memorie van Toelichting heeft hij de overweging van de commissie, die hij geheel deelt, zelfs in extenso overgenomen), is voor een novum in onze Nederlandse rechtspleging gezorgd. Iedere belanghebbende die van oordeel is dat een jaarrekening niet aan de eisen van de wet voldoet, als ook de procureur-generaal bij het gerechtshof te Amsterdam, zal binnen de hiervoor reeds genoemde termijn een vordering bij de ondernemingskamer van het gerechtshof te Amsterdam tegen de betrokken onderneming kunnen instellen. De ondernemingskamer houdt zitting en beslist met leden van het gerechtshof en twee niet tot de rechterlijke macht behorende deskundigen. Het bevel dat de ondernemingskamer bij toewijzing der vordering zal uitvaardigen zal nauwkeurige aanwijzingen bevatten die de bestuurders van de ondernemingen bij het opmaken van een jaarrekening in acht moeten nemen; het bevel betreft hetzij de jaarrekening in kwestie, hetzij een of meer toekomstige jaarrekeningen, hetzij beide. In het eerste geval heeft het bevel de nietigheid van de vaststelling of goedkeuring van de jaarrekening in kwestie tot gevolg, de ondernemingskamer kan de gevolgen der nietigheid echter beperken. Alsdan zal de ondernemingskamer de bestuurders der onderneming opdracht geven binnen een door haar te stellen termijn een nieuwe jaarrekening op te maken.

Indien de omstandigheden zich hebben gewijzigd kan de ondernemingskamer op verzoek van de onderneming een eerder gegeven bevel, voor zover dat op toekomstige jaarrekeningen betrekking heeft, intrekken.

Het als afsluiting in artikel 35 opgenomen verbod een dusdanig rechterlijk bevel niet na te komen, legt via artikel 43 voor gevallen waarin dat nodig is de band met de strafrechter.

Zie hier in grote trekken het systeem dat in het Ontwerp wet op de jaarrekening van ondernemingen voor de rechtspleging inzake jaarrekeningen wordt voorgesteld.

Moge het zó zijn, dat de ondernemingskamer slechts een bescheiden arbeidsterrein zal aantreffen en dit mede door de bijdragen die de Nederlandse registeraccountants zullen leveren, zowel in de oordeelsvorming over de algemene vraagstukken met betrekking tot de jaarrekening, als bij de keuze van oplossingen in specifieke gevallen. 
Opgave van enige literatuur die (mede) betrekking heeft op boofdstuk IV van bet rapport Herziening van bet ondernemingsrecht, uitgebracht door de CommissieVerdam ${ }^{28}$ )

\section{Publikaties in de Accountant:}

september 1965 - De jaarverslaggeving van naamloze vennootschappen. Preadvies met bijlagen van A. F. Tempelaar voor de Accountantsdag 1965.

januari 1966

- Idem, verslag middagvergadering Accountantsdag 1965.

juli/aug. 1966

- Nota d.d. 27 juli 1966 van de besturen van het N.I.v.A. en van de V.A.G.A. inzake het voorontwerp van de commissie-Verdam van wet op de jaarrekening van ondernemingen.

februari 1967 - Voorontwerp van wet op de jaarrekening van ondernemingen.

Verslag van de studievergaderingen van het N.I.v.A. en de V.A.G.A. gehouden op 17 en 24 september 1966.

maart 1967

- Brieven van 25 januari 1967 en 8 maart 1967 van de besturen van het N.I.v.A. en de V.A.G.A. aan de Minister van Justitie inzake het Voorontwerp van wet op de jaarrekening van ondernemingen.

mei 1967

- Redes van A. F. Tempelaar en J. Kraayenhof in de eerste bijeenkomst op 28 april 1967 van de ledenvergadering van de Orde Nederlands Instituut van Registeraccountants.

\section{Artikelen in het Maandbiad voor Accountancy en Bedrijfshuishoudkunde:}

juni 1965

- Een voorontwerp van een wet op de jaarrekening van ondernemingen door Prof. A. M. van Rietschoten.

- Het rapport van de Commissie-Verdam en de Werkgeversrapporten inzake de verslaglegging van ondernemingen door Prof. Dr. H. J. van der Schroeff.

april 1966

- Enkele misvattringen en misverstanden in en rond hoofdstuk IV van het rapport-Verdam door Prof. A. B. Frielink.

november 1967 - De toelichting als onderdeel van de jaarrekening door Prof. A. Goudeket.

\section{Artikelen in De Naamloze Vennootschap:}

april/mei 1965 - De jaarverslaggeving volgens het rapport van de Commissie-Verdam, bezien vanuit het gezichtspunt van de accountant door Prof. Drs. G. L. Groeneveld.

oktober, november en december 1965

- Enige opmerkingen over het voorontwerp van een wet op de jaarrekening van ondernemingen door Mr. Th. S. IJsselmuiden.

september 1966 - Het advies van de Sociaal Economische Raad inzake de wetgeving over de jaarrekening van ondernemingen door Dr. B. Prujjt.

Artikel in het Tïdschrift voor Vennootschappen Verenigingen en Stichtingen:

maart 1965

- De jaarrekening van ondernemingen door Prof. Drs. R. Burgert.

28) Staatsuitgeverij, 's-Gravenhage 1965. 
Artikel in Economisch-Statistische Berichten:

11 augustus 1965 - „Het voorontwerp van een wet op de jaarrekening van ondernemingen” van de Commissie-Verdam op de keper beschouwd door Prof. Drs. R. Burgert.

\section{Diverse publikaties:}

Onderneming en jaarverslag.

Publicatie van J. M. Vecht in de serie Onderneming en Leiding, Alphen aan de Rijn, 1965.

Advies inzake de wergeving over de jaarrekening van ondernemingen, met bijlagen.

Uitgave van de Sociaal-Economische Raad, 1966 no. 4.

Wensen en grenzen.

Enige beschouwingen over de jaarrekening van ondernemingen.

Openbare les van Drs. H. H. J. Nordemann, gehouden op 24 oktober 1967. 